\title{
Canibais do Brasil: os açougues de Fries, Holbein e Münster (Século XVI)*
}

Yobenj Aucardo Chicangana-Bayona**

O artigo estuda a cartografia alemã da primeira metade do século XVI. Principalmente, enfoca-se na imagética realizada por Lorenz Fries, Hans Holbein e Sebástien Münster sobre grandes açougues, nos quais os indígenas do Brasil devoravam uma infinidade de membros humanos. O texto faz uma análise das vinhetas, que mostram o repasto canibal, percorrendo as influências medievais na representação do canibalismo do Novo Mundo.

Palavras-chave: Cartografia - Canibalismo - Brasil - Antropofagia

Cannibals of Brazil: The slaughter houses of Fries, Holbein and Münster (S. XVI)

The focus of the present article is German cartography of first half of the XVI century, in particular the images created by Lorenz Fries, Hans Holbein and Sebástien Münster of the huge slaughter houses where Brazilian natives were shown devouring human bodies. The text analyzes the vignettes, which show cannibalistic practices, showing how medieval beliefs influenced the representation of cannibalism in the New World.

Keywords: Cartography - Cannibalism - Brazil - Anthropophagism

\footnotetext{
*Artigo recebido em novembro de 2008 e aprovado para publicação em março de 2009.

** Profesor Asociado do Departamento de Historia da Facultad de Ciencias Humanas y Económicas da Universidad Nacional de Colombia, Sede Medellín, Colombia. E-mail: yobenj@ gmail.com
} 
Cannibales du Brésil: les boucheries de Fries, Holbein et Münster (XVIe siècle)

L'article analyse la cartographie allemande de la première moitié du XVIe siècle; il est centré surtout aux images realisées par Lorez Fries, Hans Holbein et Sebástien Münster sur des grandes boucheries, dans lesquelles les indigènes du Brésil dévorent une infinité de membres humains. Le texte analyse des vignettes qui montrent le répas cannibale, en parcourant les influences médiévales à la répresentation du cannibalisme au Nouveau Monde.

Mots-clés: Cartographie - Cannibalisme - Brésil - Anthropophagie

Este artigo segue os rastros dos cinocéfalos, para obter indicações sobre a construção da imagética da antropofagia medieval e suas repercussões sobre as representações do canibalismo no Novo Mundo. As vinhetas que acompanham a cartografia são o ponto de partida para o mapeamento de genealogias e diálogos entre imagens e textos do Ocidente medieval e do início da época moderna. ${ }^{1}$

\section{Mapas, cinocéfalos e açougues}

Durante o Renascimento, as elites cultas tiveram o interesse em resgatar os conhecimentos geográficos dos gregos, sendo a Geografia de Cláudio Ptolomeu (século II) uma das obras mais lidas e traduzidas do grego para o latim na primeira década do século XV, recebendo, paulatinamente mapas-mundi e cartas parciais, as Tabulas Novas.

A Geografia de Ptolomeu é muito importante porque seria o veículo para a divulgação dos avanços do conhecimento cartográfico, embora os textos e mapas originais tenham sido ultrapassados. As sucessivas edições da obra disseminaram os modernos mapas desenhados pelos cartógrafos europeus, diretamente informados pelas viagens de expansão e conquista. ${ }^{2}$

\footnotetext{
${ }^{1}$ Agradecimentos especiais às Professoras Célia Cristina da Silva Tavares e Maria Eugênia Mattos, pela ajuda com o português.

${ }^{2} O$ Tesouro dos Mapas. A cartografia na Formação do Brasil, São Paulo, Instituto Cultural Banco Santos, 2002, p.80.
} 
Um destes casos foi o de Lorenz Fries, que fez uma famosa xilogravura, em 1525, para acompanhar a reedição da Geografia de Ptolomeu, feita por Martin Waldseemüller, sobre canibais do Brasil com cabeça de cachorro (fig. 1).

No centro da uma paisagem aprazível, destacam-se dois cinocéfalos retalhando um corpo humano em uma espécie de açougue: o primeiro deles, com uma machadinha, acaba de cortar os pedaços restantes do corpo, e, sobre a mesa, ainda pode-se ver uma cabeça e talvez o que resta de uma perna; um segundo cinocéfalo parece pegar as partes que o primeiro corta. Na parte superior desse improvisado abatedouro, vê-se um varal com membros humanos pendurados, provavelmente partes da vítima recentemente retalhada.

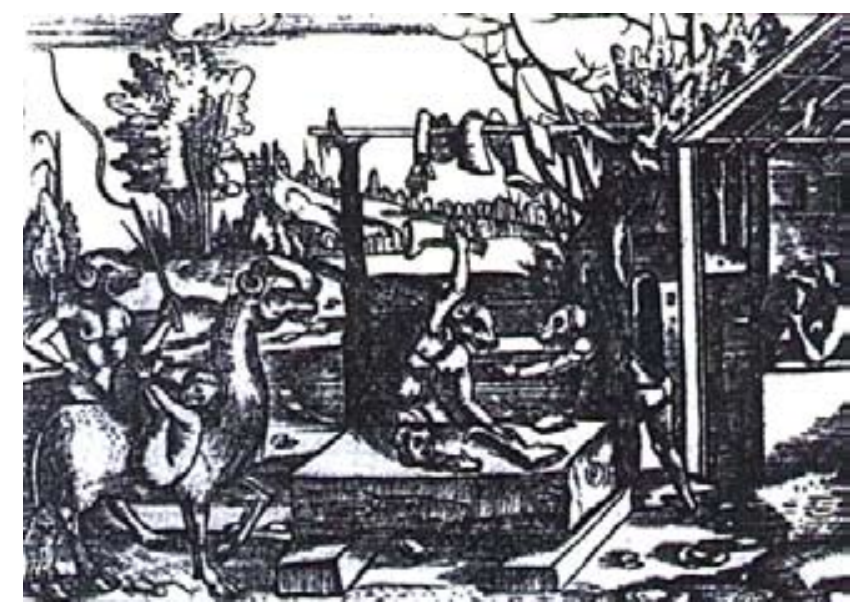

Figura 1 - Lorenz Fries. Canibais com cabeça de cachorro. Uslegung Der Mer Carthen. Xilogravura. Estrasburgo, 1525.

No lado direito da xilogravura aparece o interior de uma cabana, onde outro canibal com cabeça de cachorro devora partes de um corpo. À esquerda, um quarto cinocéfalo recém-chegado tem uma vara nas mãos e parece conduzir uma montaria, um animal híbrido, corpo de cavalo, pescoço e rosto de camelo ${ }^{3}$

\footnotetext{
${ }^{3}$ Antonio Pigafetta descreve um animal nas suas crônicas, próximo à imagem da gravura e do qual ele teve notícia na Patagonia: “(...) tiene la cabesa y las orejas grandes como una mula, el cuello y el cuerpo del camello, las piernas del ciervo y la cola del caballo, cuyo relincho imita: hay muchisimos en esta tierra (...)". Antonio Pigafetta, La primera vuelta al mundo. Las mejores crónicas marinas I, Buenos Aires, Editora Ameghino, 1998, p. 49.
} 
e chifres curvos. ${ }^{4}$ Presa a ele, uma figura que parece ser uma mulher, está com pés e mãos atados, indicando ser a próxima vítima a ser sacrificada.

Esta xilogravura de Fries sobre os habitantes do Novo Mundo está influenciada pelos relatos medievais de Marco Polo e especialmente os escritos de Mandeville. ${ }^{5}$ Mas por que Colombo e depois Fries fariam esta analogia? Seguir o rasto dos cinocéfalos pode dar indicações sobre a construção da imagética da antropofagia medieval e suas repercussões na representação do canibalismo no Novo Mundo.

A associação dos índios canibais do Novo Mundo e os lendários homens com cabeça de cachorro devoradores de carne humana aparece inicialmente na escrita, no diário da Primeira Viagem de Colombo, Domingo, 4 de novembro:

(...) Entendeu também que longe dali havia homens de um olho só e outros com cara de cachorro, que eram antropófagos e que, quando capturavam alguém, degolavam, bebendo-lhe o sangue e decepando as partes pudendas (...). ${ }^{6}$

Na Segunda, 26 de novembro, novamente Colombo faz referência aos cinocéfalos:

(...) Toda a gente que encontrou até hoje diz que sente o maior medo dos "caniba" ou "canima" que vivem nessa ilha de "Bohio". Não queriam falar, por receio de serem comidos, e não podia tirar-lhes o medo, pois diziam que só tinham um olho e cara de cachorro (....).

$\mathrm{Na}$ carta de Colombo ${ }^{8}$ se permeia a visão de um Oriente visto como paraíso, repleto de monstros e riquezas, herdada da Baixa Idade Média e que é transladada para o Novo Mundo, como Guillermo Giucci oportunamente anota:

(...) A Ásia encarnou, com seus interiores ignotos, confins imaginários e impérios formidáveis, o reino dos prodígios para os europeus da Baixa Idade

\footnotetext{
${ }^{4}$ A identificação do animal com uma lhama por alguns especialistas é problemática, já que o contato com estes animais ocorreu nos Andes, tempo depois, com a exploração do Peru; portanto, posterior à data da confecção da vinheta.

${ }^{5}$ Philip P. Boucher, Cannibal Encounters. European and island Caribs, 1492-1763, Baltimore and London, The Johns Hopkins University Press, 1992, p. 19.

${ }^{6}$ Cristóvão Colombo, Diários da descoberta da América: as quatro viagens e o testamento, Tradução de Milton Persson, Porto Alegre, L\&PM, 2001, p. 71.

${ }^{7}$ Cristóvão Colombo, op. cit., p. 81.

${ }^{8}$ Francisco Morales Padrón, Teoría y leyes de la conquista, Madrid, Ediciones Cultura Hispánica / Centro Iberoamericano de Cooperación, 1974, p. 149-154.
} 
Média. O maravilhoso medieval construiu-se de anomalias, desde monstros pavorosos, como arimaspos e blêmios, até paraísos. Não obstante, do conjunto de elementos que o formou destacaram-se os metais preciosos, em particular o ouro e a prata... implicavam um deslocamento do impreciso ao identificável. Inserida num cenário de ilusões, esta transição do desconhecido ao desejado desembocou, numa primeira etapa da conquista, no horizonte do extraordinário (....) ${ }^{9}$

O Oriente era o lugar por excelência do maravilhoso. ${ }^{10}$ A visão do Oriente, as maravilhas da Índia, o mare clausum (Índico), na concepção medieval, estão baseados em fontes helenístico-latinas e nas descrições lendárias iniciadas por Ctésias de Cnido e Megástenes no século IV a.C. Le Goff afirma que “(...) O oceano Índico é o mundo fechado do exotismo onírico do Ocidente medieval, o hortus conclusus de um paraíso cheio de encantamentos e de pesadelos (...)". ${ }^{11}$

Entre as raças de seres monstruosos, herdadas de Plínio e Solino, os que tinham cabeça de animal figuravam dentre os mais famosos durante toda a Idade Média, especialmente por estarem presente na maioria dos relatos de viagem ao Oriente e ao Ocidente, descritos nos bestiários e usados como temas nos sermões.

Sobre os cinocéfalos, Santo Agostinho comenta: “(...) Que direi dos Cinocéfalos, cuja cabeça de cão e o próprio latido os fazem tomar mais por animais do que por homens? (...)". ${ }^{12}$ Isidoro de Sevilha também os descreve: “(...) Cynocephali appellantur eo quod canina habeant, quosque ipse latratus magis bestias quam homines confiteur. Hi in India nascuntur (...)".13

Tanto Agostinho como Isidoro, ao transmitirem as descrições dos seres prodigiosos $^{14}$ dos velhos acervos geográficos da Antiguidade, contribuíram

\footnotetext{
${ }^{9}$ Guillermo Giucci, Viajantes do Maravilhoso. O Novo Mundo, São Paulo, Companhia das Letras, 1992, p. 13.

${ }^{10}$ Laura de Mello e Souza, O diabo e a Terra de Santa Cruz: feitiçaria e religiosidade popular no Brasil Colonial, São Paulo, Companhia das Letras, 1986, p. 24-25.

${ }^{11}$ Jacques Le Goff, Para um Novo Conceito de Idade Média. Tempo, trabalho e cultura no Ocidente, Lisboa, Editorial Estampa, 1980, p. 265.

${ }^{12}$ Agostinho de Hipona, A Cidade de Deus, Lisboa, Fundação Calouste Gulbenkian, 1995, 3 vol., XVI, 8.

13 “(...) Os cinocéfalos devem seu nome por terem cabeça de cachorro; seus mesmos latidos põem de manifesto que se tratam mais de bestas que de homens. Nascem na Índia (...)”. Isidoro de Sevilla, Etymologiae, XI, 3.

${ }^{14}$ Sobre os seres prodigiosos na obra de Isidoro de Sevilha, ver o artigo de Ruy de Oliveira Andrade Filho, "A respeito dos homens e dos seres prodigiosos. Uma utopia do homem e de sua existência na obra de Santo Isidoro de Sevilha", Revista da USP, 23, 1994, p. 77-83.
} 
para difundir estas criaturas no imaginário medieval. Na Baixa Idade Média, os cinocéfalos novamente ganhariam grande destaque nos relatos de viagem de Mandeville, Marco Polo e Jourdain de Séverac, autores que também vão priorizar nas suas descrições os hábitos antropofágicos. A descrição de Colombo é muito próxima da dos cinocéfalos, habitantes da ilha de Angamã, referidos por Marco Polo:

(...) Angamã é uma ilha muito grande, sem lei nem rei. Os habitantes são idólatras, vivem como os animais selvagens. Temos a apontar uma estranha visão desta gente. Nesta ilha, os homens têm cabeça e dentes de cão, e sua cara parece-se com a dos mastins. São muito cruéis e comem quantos homens possam apanhar e que não sejam de sua tribo. Têm especiarias variadas e abundantes. Alimentam-se de arroz, leite e toda a espécie de carnes. As frutas que comem são muito diferentes das nossas (......15

Desde muito cedo na literatura antiga, como é o caso da Odisseia, já se fazem referências à antropofagia vinculada à monstruosidade. No épico retorno de Ulisses ao seu reino Ítaca, o herói tem que sobreviver ao gigante ciclope antropófago Polifemo. A enormidade é acompanhada pela ferocidade e pela antropofagia. ${ }^{16}$ Plínio, o velho (século I d.C.), na Naturalis Historia, relaciona as práticas do consumo de carne humana a lugares inóspitos em que são frequentes a presença de criaturas fantásticas e seres monstruosos. ${ }^{17}$

A presença de monstros e povos que se alimentam de carne humana nas descrições sobre o Oriente já estão presentes na tradição antiga greco-latina, sobrevivendo durante toda a Idade Média. Isidoro de Sevilha os descreve assim: “(...) Cyclopes quoque eadem India gignit;et dictos Cyclopes eo quod unum habere oculum in fronte media perhibentur. Hi et $\alpha \gamma p \mathrm{p} \varphi \alpha \gamma i \tau \alpha$ dicuntur, propter quod solas ferarum carnes edunt (...)". ${ }^{18}$

Numa iluminura da chamada Bíblia de Arstein, do século XII, se apresenta a visão de mundo do homem medieval a respeito dos habitantes de terras distantes: Oriente, Índia, Líbia, Etiópia e Cítia, seguindo as descrições dos

$\overline{{ }^{15} \text { O Livro da Índia, Parte XX: da ilha de Angamã, p. 173, in: Marco Polo, O Livro das Mara- }}$ vilhas. A descrição do Mundo, 4. ed., Porto Alegre, L\&PM, 1994. Os grifos são meus.

${ }^{16}$ Claude Kappler, Monstros, demônios e encantamentos no fim da Idade Média, Rio de Janeiro, Martins Fontes, 1994, p. 178.

${ }^{17}$ Pline, NATURALIS HISTORIE, Liber VII Continetur hominum generatio et institutio, atque inventio artium; II. Gentium mirabiles figura, I.

18 “(...) Também a Índia engendra ciclopes. E são denominados “ciclopes” porque ostentam um olho no meio da testa. Também são designados como agriophagîtai ( $\alpha \gamma p l o \varphi \alpha \gamma(\tau \alpha)$ ), porque só alimentam-se com carne de feras (...)”. Isidoro de Sevilla, Etymologiae, XI, 3, 16. 
seres prodigiosos feitas por Isidoro de Sevilha, nas Etymologiae, XI, 3, 1-39 (fig. 2).

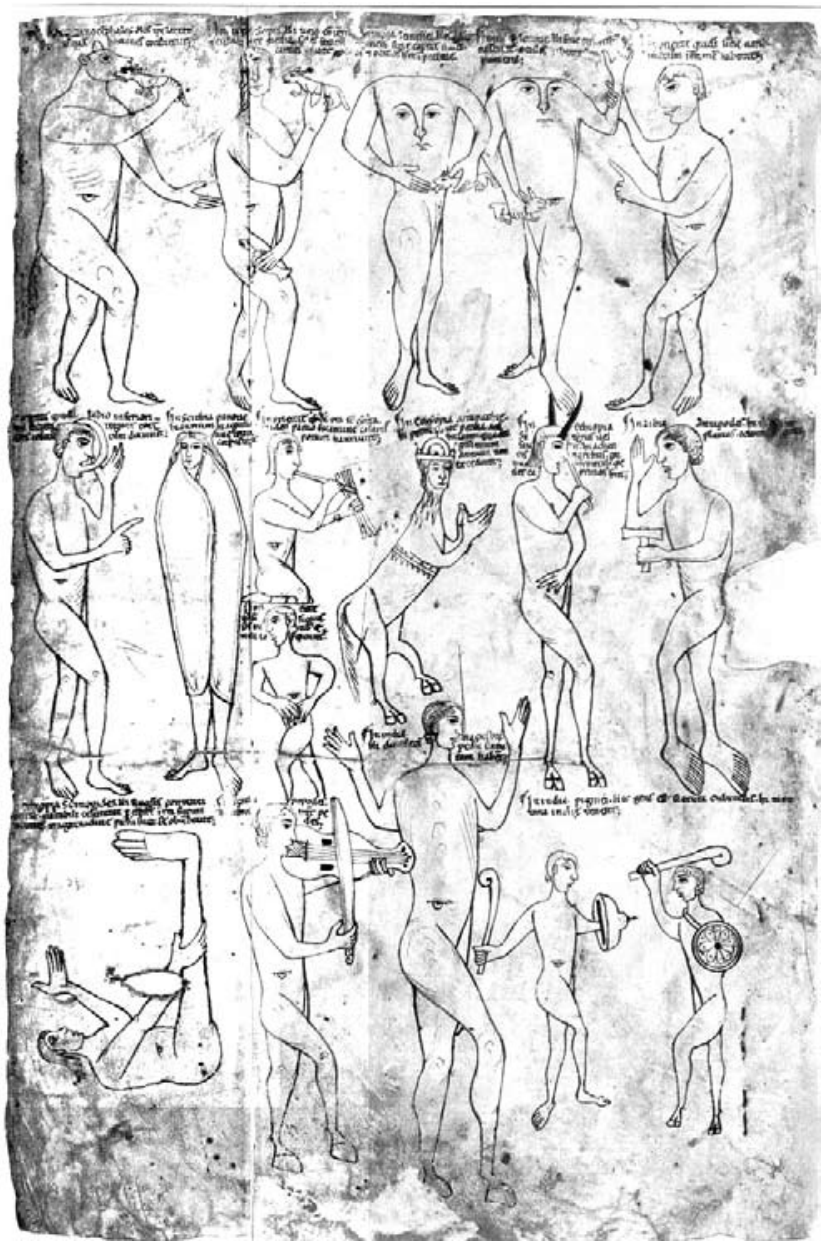

Figura 2 - Habitantes das Terras Distantes. "The Arstein Biblie", de Premonstratensian Abbey, Arnstein. British Museum, Londres.Cerca de 1175.

Este manuscrito é muito importante porque apresenta uma divisão geográfica e étnica; as raças monstruosas identificariam os povos das principais regiões do mundo. Note-se que durante toda a Idade Média a teratologia herdada da tradição clássica sobreviveria formando parte do maravilhoso - um 
maravilhoso que se apoia no desconhecimento, mas não exige a concordância entre o objeto e o narrado. ${ }^{19}$

No manuscrito iluminado, os cinocéfalos, os ciclopes e as blêmias ganham destaque ao estar segurando animais em suas mãos. Só que, no caso dos dois primeiros, estes aparecem a ponto de devorar suas presas reforçando o apetite voraz; os agriophagîtai, "os devoradores de feras", com que Isidoro identificava os ciclopes. No manuscrito do século XII essa característica também é transladada aos cinocéfalos, que na iluminura aparecem representados com mais voracidade que os ciclopes, porque sua presa já está dentro da boca. ${ }^{20}$ Portanto, as criaturas com corpo humano e cabeça de cachorro, como os cinocéfalos, ou os seres com um olho só, como os ciclopes, eram bastante familiares nos sermões e nas leituras morais do Medievo, tendo sua tipologia definida ${ }^{21}$ do mesmo modo que seu caráter destrutivo e voraz. ${ }^{22}$ Le Goff afirma que “(...) Desde a Antiguidade grega, o monoculismo é o símbolo da barbárie no Ocidente, e os Cristãos medievais povoam a Índia de Ciclopes (...)". ${ }^{23}$

A xilogravura de Fries vai integrar os cinocéfalos do Oriente e suas características antropofágicas e vai transpô-las para os Canibais do Ocidente, demonstrando a influência das lendas e as tradições medievais, como assinala Frank Lestringant:

(...) A intrusão de elementos com cabeça de cão no teatro do Novo Mundo traduz a impressionante força dos mitos legados pela Antiguidade. Mas ela opera, por outro lado, uma espécie de condensação fantasmagórica. Testemunhas do imaginário americano em seu estado arcaico, os açougueiros cinocéfalos de Estrasburgo conjugam o canibalismo real dos povos do Extremo-Ocidente com a suposta aparência canina daqueles do Oriente. Entre os dois, a ligação é feita por um jogo de palavras - canis-caniba. ${ }^{24}$

\footnotetext{
${ }^{19}$ Guillermo Giucci, op. cit., p. 14.

${ }^{20}$ As catalogações de raças monstruosas aparecem em muitos tratados e obras, durante toda a Baixa Idade Média, como o caso da Imago Mundi, de Pierre d’Ailly, no século XV.

${ }^{21}$ (...) "Os Pigmeus são o símbolo da humildade, os Gigantes são o símbolo do orgulho, os Cinocéfalos o símbolo das pessoas quizilentas, sendo assim reduzidos à humanidade vulgar. A domesticação processa-se ao longo de uma evolução que transforma as alegorias míticas em alegorias morais e que finalmente as degrada até ao nível da sátira social (...)”. Jacques Le Goff, Para um Novo Conceito de Idade Média. Tempo, trabalho e cultura no Ocidente, Lisboa, Editorial Estampa, 1980, p. 273.

${ }^{22}$ Kappler, Monstros, op. cit., p. 230-235.

${ }^{23}$ Jacques Le Goff, Para um Novo Conceito de Idade Média. Tempo, trabalho e cultura no Ocidente, p. 280.

${ }^{24}$ Frank Lestringant, op. cit., p. 34.
} 
Se nas xilogravuras de Vespúcio começava-se a insinuar as mesas de sacrifício das vítimas do repasto canibal, com Fries, os lugares de sacrifício ganham características de abatedouros e açougues, com inúmeras partes humanas retalhadas e penduradas, confirmando assim a carne humana como dieta gastronômica dos novos cinocéfalos.

Entretanto, serão as impressionantes imagens de Hans Holbein na cartografia da primeira década do século XVI que vão combinar muitas das convenções estabelecidas desde as primeiras gravuras, gerando um espetáculo macabro do quotidiano do habitante do Novo Mundo e suas práticas de canibalismo: açougues, espetos, corpos sendo retalhados, pendurados e cozinhados em panelas.

É importante, antes de continuar, fazer um esclarecimento tipológico: as cartas geográficas para o século XVI podem ser organizadas em dois grandes grupos. $\mathrm{O}$ primeiro, de mapas mais exatos, feitos para informações precisas, prática de marinheiros, viajantes, cientistas, estrategas e militares. O segundo grupo de mapas, mais belamente decorados, com vinhetas de episódios, desenhos e pinturas, feitos para o prazer visual e para serem consumidos por uma elite erudita e humanista interessada pelas viagens e os relatos destas. Estes mapas podiam circular como folhas soltas ou em livros. Com a invenção da imprensa e a sofisticação das técnicas, a gravura foi modificando a difusão do conhecimento cartográfico, podendo se reproduzir em grandes quantidades, em menor tempo e com barateamento de custos, ampliando o arco de cobertura e a quantidade de indivíduos que as consumiam. ${ }^{25}$

$\mathrm{Na}$ cartografia, a referência ao canibalismo aparece pela primeira vez entre 1503-1506, no mapa "Novo Mundo", atribuído a Bartolomeu Colombo e a Alessandro Zorzi. Nesse mapa aparece uma ilha como o nome de Canibali, aquela mencionada no diário da primeira viagem de Colombo. Pedro Martir de Angleria, em 1504, também informava a Ascanio Sforza da presença de duas ilhas de canibais. ${ }^{26}$ Canibalia, a terra dos canibais, durante a primeira metade do século XVI, irá deslocando-se das Antilhas para o continente e a terra do Brasil e dos índios caribes aos Tupinambá, como terminará se confirmando nos mapas de Holbein e Münster.

${ }^{25}$ Margarita Lira, "La Representación del Indio en la Cartografía de América", in: Revista Chilena de Antropología Visual, n. 4, Santiago, Julio 2004, p. 88.

${ }^{26}$ Carlos Jáuregui. "Brasil especular: alianzas estratégicas y viajes estacionarios por el tiempo salvaje de la Caníbalia", in: Heterotropías: narrativas de identidad y alteridad latinoamericana IILI, 2003, Vanderbilt University, p.79. 
No mapa Novus Orbis Regionum, feito por Hans Holbein, em 1532 (fig. 3), na parte dedicada ao Novo Mundo apresentam-se vinhetas de emblemas: animais atacando homens, animais híbridos, monstros, homens selvagens e cenas de canibalismo. Os episódios sobre canibais que acompanham o mapa na parte inferior são mais complexos e elaborados que os anteriores, de Waldseemüller e Lorenz Fries.

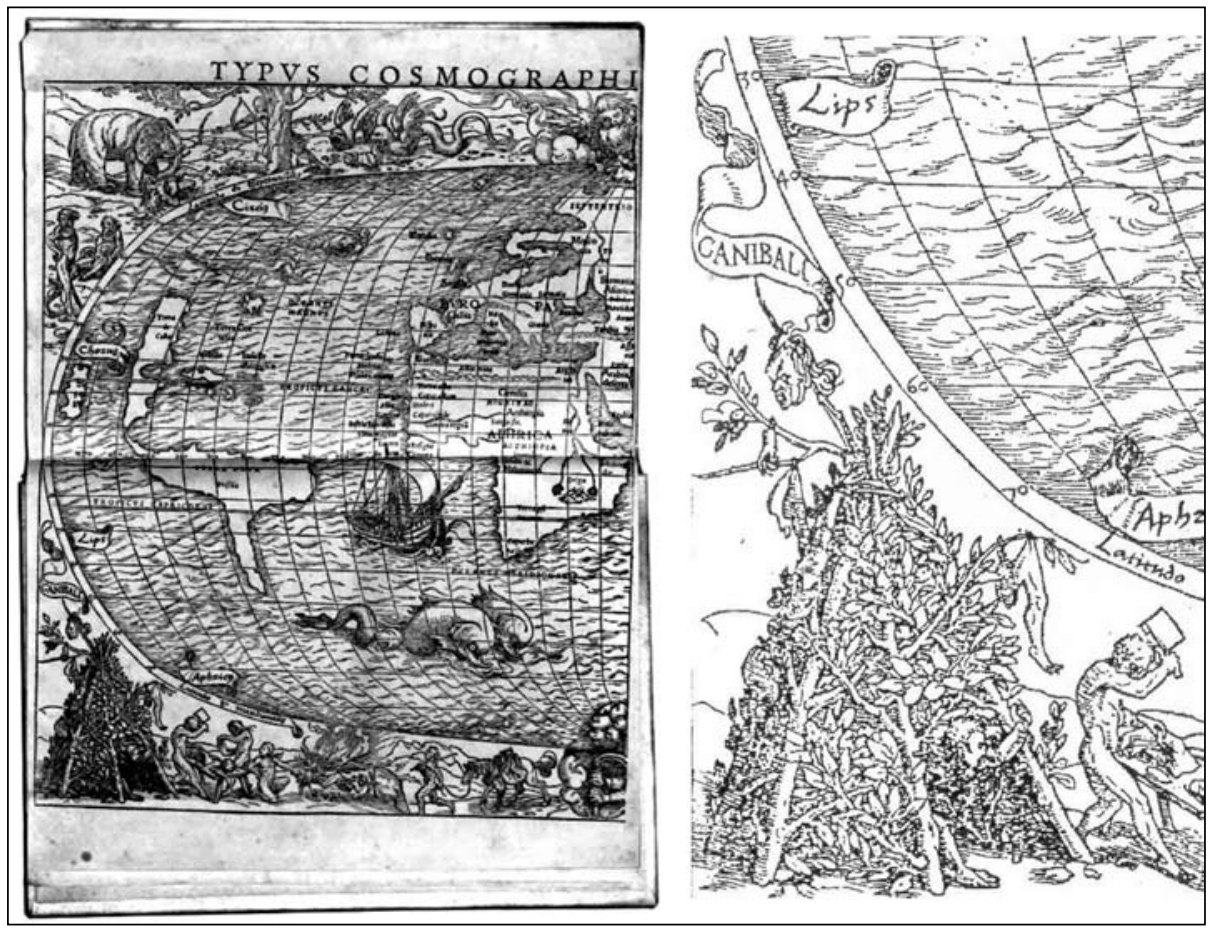

Figura 3 - Detalhes da Novus Orbis Regionum. H. Holbein, o novo. Biblioteca da Universidade de Kontanz. 1532.

No canto inferior esquerdo aparece uma barraca, um abrigo rústico feito com materiais como folhas e galhos, que proporcionam a aparência de um arbusto. Em alguns galhos estão penduradas partes humanas tais como uma perna, uma mão e uma cabeça, e sobre elas aparece a expressão "canibali". Holbein substitui a famosa árvore com membros humanos retalhados e pendurados, típica das cosmografias, supostamente um costume praticado pelos habitantes do Novo Mundo, por uma cabana rústica de galhos. Aárvore, 
sob a qual os índios canibais devoravam carne humana, converte-se na Novus Orbis Regionum, no lar dos canibais.

Na parte esquerda da barraca parece emergir dentre os galhos e folhas uma cabeça humana, não ficando muito claro se é uma cabeça pendurada do repasto canibal ou um morador que olha através de uma "janela" do abrigo. $\mathrm{Na}$ entrada da barraca, aparece um homem ajoelhado, do qual só se vê parte dele, que faz sinais aos que estão fora da cabana.

Na parte externa do abrigo aparecem três canibais: o primeiro é um homem e porta um machado retalhando um corpo humano em uma mesa, sendo auxiliado por uma mulher, que parece pegar as partes cortadas; a terceira figura, um homem ajoelhado, assa um ser humano em um espeto giratório. No fundo, atrás do homem e do espeto, pode-se visualizar no fogo dois caldeirões de comida com uma mão aparecendo. Aqui, Holbein tem toda a intenção de mostrar ao espectador que o conteúdo que está sendo cozinhado é carne humana, embora, esta mão ao sair do caldeirão ficaria crua.

Na parte direita da cena pode-se ver chegando uma outra personagem que traz um cavalo e nele uma figura nua (talvez uma mulher) pendurada pelos pés e mãos, como normalmente se transportavam presas de caça. Isto indica que o homem que está chegando estaria trazendo outra vítima para o banquete preparado pelos outros personagens.

Sebastien Münster ${ }^{27}$ realiza a prancha Novus Orbis, Die Nüw Welt ${ }^{28}$, xilogravura com data de 1540, feita em Basileia e incluída na sua versão re-

27 “(...) A Cosmografia de Münster, editada em alemão, em 1544 e traduzida para o latim em 1550 teve grande repercussão entre o público erudito, a quem foi destinada. Nesta obra bastante ilustrada, Sebastien Münster re-publicou a carta inserida em sua edição da Geografia de Ptolomeu (1540) (...)”, p. 82.

${ }^{28} \mathrm{O}$ mapa tem uma riqueza de informações que situam as descobertas recentes no Caribe e no Atlântico, e a divisão das possessões entre portugueses e espanhóis. A América aparece separada da Ásia. Aparecem nomes de ilhas como Cuba, Hispaniola e Dominica e Cozumel, entre outras. A América Central já aparece como um istmo, mas Yucatán (Iucatana) aparece como ilha. Um curioso destaque para a localização da capital do Império Azteca, que aparece no mapa como Temistitan. Na parte meridional, o continente continua aparecendo como terra de gigantes, a Regio Gigantum. Münster, da mesma forma que Waldseemüller, batizará nos seus mapas o estreito sul em homenagem a Magalhães. Daí por diante, os habitantes dessas terras serão identificados nas gravuras e mapas como Magellanici. No mapa xilogravado aparece uma parte da Ásia identificando lugares como India Superior, Cathay (China) e a cidade de Quinsay (Changáan) e ilhas como Zipangri (Japão) e o Archipelagus 7448 insularu, nomes baseados nas descrições de Marco Polo, no seu Livro das Maravilhas: “(...) Este mar, onde a ilha de Cipango está situada, chama-se o mar da China e é o mesmo mar que banha as costas de Mangi; e os naturais desta ilha, quando falam da China, querem dizer Mangi; porém, a China está para o Levante e tem, segundo os pilotos e navegadores que a conhecem, 7448 ilhas; muitas são habitadas e não há aqui árvore que não seja aromá- 
editada da Geografia. Esse mapa seria muito popular na Europa, ainda que para um público não especializado em cartografia. Esse mapa vai situar um abrigo de galhos e folhas onde estão penduradas partes humanas no Brasil $^{29} \mathrm{e}$ é reforçado pelo texto canibali. ${ }^{30}$ Da mesma forma que no mapa de Holbein, a cabana ou abrigo de galhos substitui a árvore com membros retalhados das cosmografias (fig. 4).

O abrigo do mapa de Münster está espelhado no de Holbein; a entrada ficou orientada para a esquerda, quatro vigas amarradas na parte superior sustentam a cabana, dando-lhe um aspecto triangular; da mesma forma que na cabana do mapa de Holbein há uma perna decepada pendurada em um galho sobre a entrada, e sobre a construção existe uma expressão canibali. A perna e a legenda são as únicas indicações de canibalismo.

O abrigo de Münster difere do abrigo de Holbein por não ter mais partes humanas penduradas, nem representar os moradores da cabana. Nesse sentido, a indicação de canibalismo de Münster é mais "sutil”, mais insinuada que no mapa de Holbein, que, efetivamente, mostra com detalhes a captura, a preparação e o consumo de carne humana.

Assim, os mapas de Holbein e Münster identificam porções do Novo Mundo (habitados pelos Caribes e Tupis) com as práticas canibais. Inicialmente, pode se afirmar que os episódios estão representando índios, já que ao lado da cena, sobre os abrigos, aparece a palavra "canibali". A isto deve se somar que, na cosmografia de Münster, aparece a cabana de galhos situada na área do Brasil, enquanto que na Novus Orbis Regionum de Holbein aparecem na América do Sul legendas como "Terra Nova", "América", "parias", "Brisilia" e "Canibali". ${ }^{31}$

tica e não tenha perfume forte (...)". Ver: "A idolatria e crueldade dos homens de Cipango", Parte XX, 162, p. 195, in: Marco Polo, O Livro das Maravilhas...

${ }^{29}$ Carlos Jáuregui tem outra interpretação e considera que o abrigo de galhos é uma fogueira pronta para acender. Carlos Jáuregui, "Brasil especular: alianzas estratégicas y viajes estacionarios por el tiempo salvaje de la Caníbalia", In: Heterotropias: narrativas de identidad y alteridad latinoamericana IILI, 2003, Vanderbilt University, p.79.

${ }^{30} \mathrm{O}$ mapa de Münster não tem índios representados, algumas árvores juntas para mostrar a presença de florestas espalhadas pelo continente, o abrigo referido antes e um barco que navega no Oceano Pacífico. O mapa privilegia as informações dos textos; as imagens surgem na prancha para preencher espaços, só que não deixa de ser curiosa a localização do abrigo canibal nas terras do Brasil, isto porque não só na terra brasilis viviam povos com costumes antropofágicos, estes abundavam também no Caribe. Novamente, pode ser uma referência às cartas apócrifas atribuídas a Vespúcio, Quatuor Navigationes e Mundus Novus.

${ }^{31} \mathrm{Na}$ Novus Orbis Regionum, de Holbein, aparece "Canibali" tanto no mapa da América do Sul como sobre a cabana aonde acontece o repasto. 
Canibais do Brasil: os açougues de Fries, Holbein e Münster (Séxulo XVI)

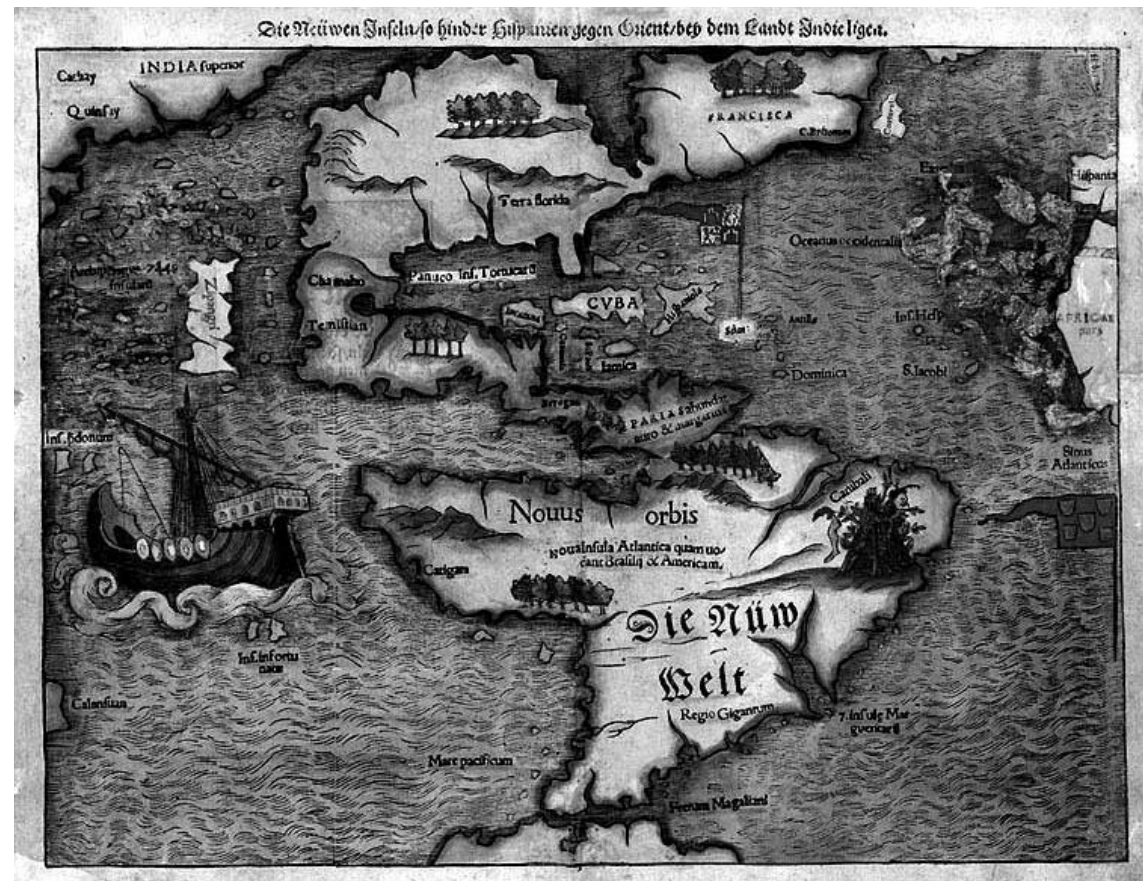

Figura 4 - Sebastien Münster. Novus Orbis, Die Nïw Welt, 34,5 x 55,8 cm. 1540

Existem várias diferenças na representação do índio praticando canibalismo no mapa de Holbein. Com relação às imagens anteriores da cartografia, por exemplo, os canibais estão nus, sem penas ou barbas. É importante destacar "as presenças alheias" dentro desta composição: o cavalo, ${ }^{32}$ os machados de

${ }^{32}$ Os cavalos eram desconhecidos dos aborígenes e foram introduzidos ao Novo Mundo pelos europeus. 
tal, ${ }^{33}$ a preparação de carne em espeto ${ }^{34}$ e a própria mesa em que o corpo está sendo retalhado, com a realidade e os costumes dos ameríndios. ${ }^{35}$

Apesar do aspecto bizarro e aterrador que a imagem possa ter, não deixa de parecer familiar. Abstraindo o repasto canibal do mapa de Holbein, a situação descreve uma imagem cotidiana de uma família camponesa qualquer do centro da Europa, transportada para uma cena do Novo Mundo. Muitos dos elementos que compõem as representações dos índios canibais são resultados da tradição pictórica europeia e não dos costumes indígenas.

Observando mais atentamente, a impressão que pode dar o canibal que retalha o corpo de um homem com um machado, sobre uma mesa, enquanto é assistido por uma mulher que vai pegando os pedaços, é a de um açougueiro. É muito similar à xilogravura anônima anterior da edição alemã da Lettera, publicada por J. Gruninger, em Estrasburgo, em 1509 (fig. 5), que mostra nos planos de fundo uma cena muito próxima da apresentada por Holbein: o índio nu cortando partes humanas; uma perna, um braço e uma mão podem ser vistos sobre a mesa; ao lado, acompanha uma mulher. As duas imagens coincidem no lugar onde a mesa sacrificial está localizada: perto da moradia dos canibais, o que dá um ar cotidiano.

\footnotetext{
${ }^{33}$ Os machados de metal não eram comuns entre os ameríndios. Estas ferramentas vão ser obtidas por meio do comércio com os europeus. Mas na iconografia o canibal que retalha o corpo humano sempre está munido de machadinha. Sobre este tema consultar o texto de Frank Lestringant. "L' Automne des cannibales ou les outils de la conquête", Michele Duchet, L'Amérique de Théodore de Bry. Une collection de voyages protestante du XVIe siècle, Paris, Editions du Centre National de la Recherche Scientifique, 1987, p. 69-104.

${ }^{34}$ Jean de Léry, em um trecho da Viagem à Terra do Brasil, questiona o costume de assar carne em espeto atribuído aos índios do Brasil nas imagens das cosmografias, chamando a atenção ao fato dos índios não conhecerem esse procedimento de cocção: “(...) Limitar-me-ei a refutar o erro daqueles que, como se pode ver em seus mapas universais, não somente nos representaram os selvagens do Brasil assando carne humana em espetos como fazemos com a de carneiro e outras... Tanto os brasileiros desconheciam o nosso modo de assar que certo dia ao nos verem em uma aldeia assando aves no espeto zombaram de nós e se recusaram a acreditar que uma ave assim continuamente volteada viesse a cozer, só o admitindo afinal pela comprovação do fato (...)". Jean de Léry, Viagem à Terra do Brasil, Belo Horizonte, Livraria Itatiaia Editora Ltda. e Editora da Universidade de São Paulo, 1980, cap. XV, p. 199. 35 “(...) $\mathrm{Na}$ ilustração, encontram-se três elementos recorrentes na cartografia alemã e lusitana: a mesa sacrificial, membros decepados e pendurados e a machadinha suspensa, pronta para cortar mais uma parte do corpo (...)". Ronald Raminelli, Imagens da Colonização, São Paulo, Jorge Zahar Editor, 1996, p. 63-64.
} 


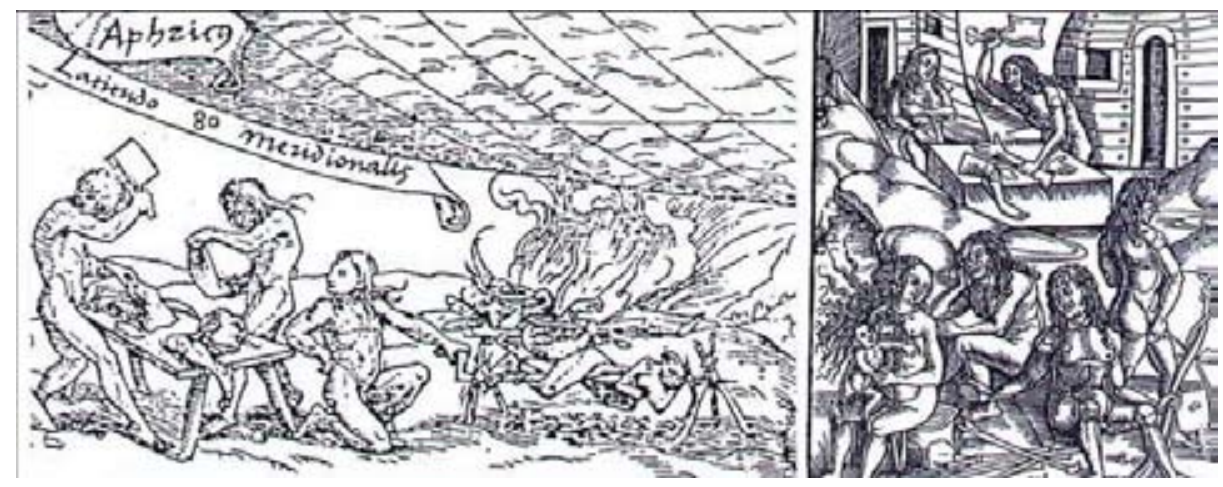

Figura 5 - Esquerda, detalhe da Novus Orbis Regionum. Hans Holbein. 1532.

Direita, xilogravura anônima. Edição alemã da Lettera publicada por J. Gruninger. Estrasburgo, 1509.

A xilogravura de Lorenz Fries, sobre canibais com cabeça de cachorro, de 1525-1527, parece inspirada na xilogravura da Lettera de Vespúcio, de 1509. Holbein, por sua vez, inspirou-se nas imagens de Fries. A xilogravura de Holbein deve muito à de Fries, onde vários elementos sobre os cinocéfalos estão presentes: a vítima presa pelas pernas e pelas mãos e carregada por um cavalo; o homem que traz a vítima também tem um pau em suas mãos, usado provavelmente para comandar o cavalo. Também são similares as posturas do canibal com a machadinha na mão direita e segurando a carne com a mão esquerda, em Holbein e em Fries. Nas duas xilogravuras o canibal que retalha o corpo é assistido por outro que vai pegando os pedaços que vão sendo cortados.

Na xilogravura de Holbein, o "açougueiro" corta seus pedaços sobre uma mesa de madeira, enquanto o cinocéfalo de Fries utiliza um enorme tronco, da mesma forma que na xilogravura da Lettera, de 1509, para retalhar o corpo.

O movimento dos homens que corta m o corpo também é similar nas três imagens (Lettera, Fries e Holbein): os canibais são representados em pé, levantando o braço que empunha um machado, antes de cortar os pedaços sobre a mesa. Este tipo de imagens é recorrente nas representações das execuções da Baixa Idade Média, como num manuscrito do século XIV, em que é representada a tortura e a execução de Simon Poulliet, prefeito de Compiègne, em Paris, em 1346, sob a vista de um grupo de padres (fig. 6). 
A imagem mostra o prefeito Poulliet deitado numa mesa e o verdugo com um machado empunhado, a ponto de dar um golpe; na imagem já aparece um membro decepado (uma perna) que está caindo da mesa. A postura do verdugo do manuscrito do século XIV é similar às do índio que corta carne nas xilogravuras da Lettera de Vespúcio, de Fries e da Carta Novus Orbis Regionum, de Holbein.

Numa edição da Legenda Áurea, feita na Itália, em 1494, acompanhada de pequenas xilogravuras, aparecem repetidas estas mesas de execução próprias da justiça secular da época para representar o martírio de santos nos primeiros séculos do cristianismo, como Terêncio e Tiago Interciso, entre outros, executados durante as perseguições dos romanos aos cristãos. Este último foi retalhado em pedaços, segundo conta a tradição piedosa, sendo que na gravura ele jaz mutilado e partes de seu corpo aparecem sobre a mesa e sobre o chão (fig. 6). Perceba-se a proximidade destas composições com a execução de Simom Poullet e com as imagens que representam os índios do Novo Mundo.

As mesas da gravura de Holbein, do manuscrito do século XIV, e as das outras gravuras dos séculos XV e XVI são muito parecidas. A mesa que aparece pode ser considerada uma mesa de suplícios e execuções utilizada pela justiça secular da época. As mesas presentes nas cenas canibais inspiravamse nas medievais, já que a morte nas mãos dos canibais era vista como uma condenação ou um sacrifício.

No entanto, a mesa tinha outras associações. Pensar no índio que corta o corpo como um açougueiro também tem cabimento, porque o repasto canibal aos olhos europeus é equivalente à alimentação, às refeições; por isso as cenas do consumo da vítima acabam por parecer parte do cotidiano. Uma imagem de um livro de salmos do século XIV, o Saltério de Luttrell, mostra alguns criados preparando um banquete: um açougueiro cortando com um facão leitões e frangos, enquanto seu ajudante pega os pedaços de carne e os coloca nos pratos. Um terceiro servente tempera outras comidas e dois mais servem (fig. 7). Note-se que a postura do cozinheiro, as mesas e até as partes retalhadas são muito similares às imagens sobre os índios canibais do Novo Mundo.

Os artistas conseguirão representar o repasto canibal partindo das imagens já feitas do seu próprio cotidiano. Assim, da mesma forma que um europeu prepara seus alimentos - leitão, galinha, cordeiro ou carne de vaca - também 
o fazem os índios canibais das terras recém-descobertas quando preparam a carne humana, em um cotidiano diabolicamente invertido.
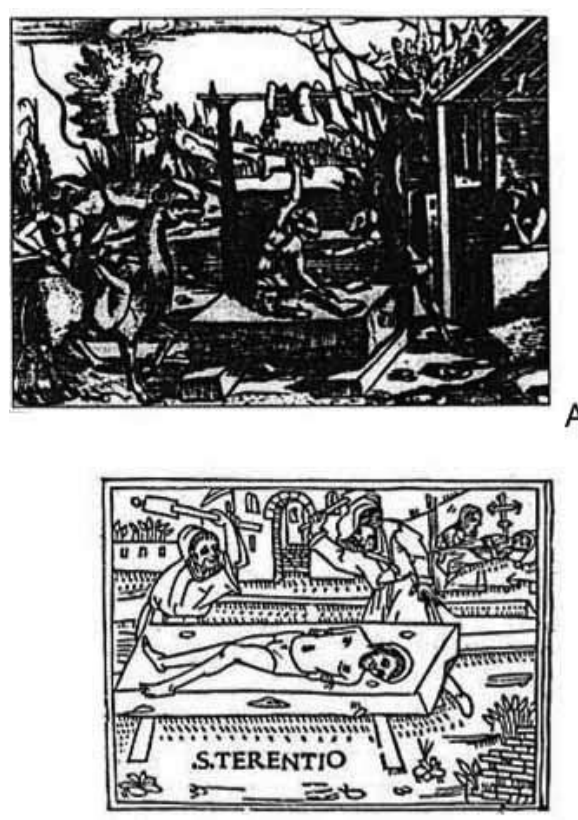
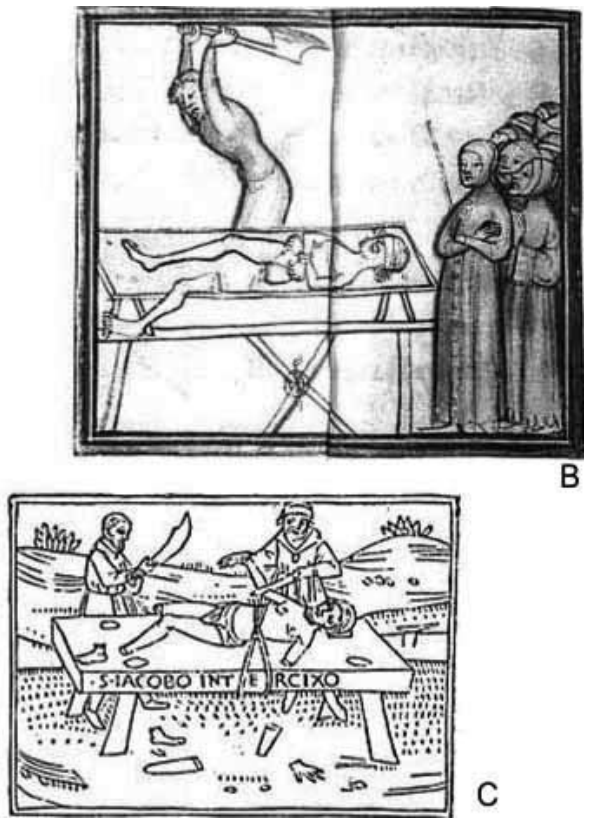

C

Figura 6 - A. Lorenz Fries, Canibais com cabeça de cachorro de 1525-1527; B.Tortura e execução de Simon Poulliet, prefeito de Compiègne em Paris, 1346. Besançon, Biblioteca Municipal. Século XIV. C. Terentio e Iacobo Intercixo. Legendi di Sancti vulgari Storiado. Veneza, 1494.

Algumas analogias com animais consumidos no cotidiano servem aos cronistas para comparar as vítimas do canibalismo. Ambrósio Fernandes Brandão narra um episódio em que um índio executa seis crianças que tinha raptado dos seus inimigos, depois de ter assaltado uma aldeia, e afirma que "as levara como galinhas". Jean de Léry, ao descrever um ritual antropofágico, comenta: “(...) chegam com água fervendo, esfregam e escaldam o corpo a fim de arrancar-lhe a epiderme; e o tornam tão branco como na mão dos cozinheiros os leitões que vão para o forno (...)”. André Thevet descreve: “(...) Ali, executam-no do mesmo modo como se mata um porco: a porretadas (...)". ${ }^{36}$

${ }^{36}$ Ambrósio Fernandes Brandão, Diálogos das Grande $a$ as do Brasil 1627, Introdução de Capistrano de Abreu e Notas de Rodolfo Garcia, Salvador, Livraria Progresso Editora, 1956, Diálogo Sexto, p. 343. Jean de Léry, Viagem à Terra do Brasil, Belo Horizonte, Editora da Universidade de São Paulo/Editora Itatiaia, 1980, cap. XV, p. 198. André Thevet, As 


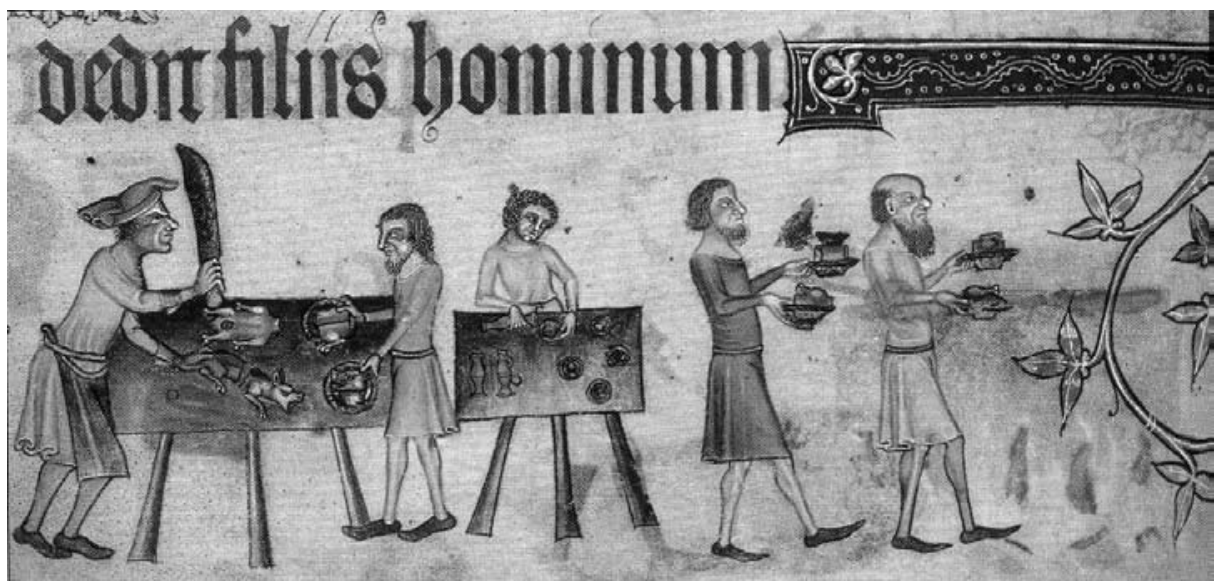

Figura 7 - Criados preparam um banquete para seus senhores.

Vinhetas da vida Inglesa, Saltério de Luttrell. Século XIV.

Jean de Léry questiona este tipo de imagens que ele encontra nos mapas universais, tais como índios cortando a carne de suas vítimas sobre bancos “(...) mas ainda no-los pintaram a cortá-la sobre bancas, com grandes cutelos, como entre nós os carniceiros fazem com a carne de vaca (...)”.37

Sob o ponto de vista iconográfico, os “espetos” dos canibais estão muito próximos das empalações, uma pena da justiça secular muito representada nas gravuras, até o século XIX. As empalações e os espetos vão ser levados a diferentes contextos, não só para descrever costumes dos selvagens americanos, mas também para mostrar a barbárie e a selvageria dos próprios europeus, sejam católicos ou protestantes; estas imagens tiveram grande difusão durante as guerras de religião. Um bom exemplo deste traslado contextual encontra-se em uma gravura protestante anônima do século XVII, que ilustra a Histoire Générale des Églises Evangéliques du Piémont ou Vaudoises, de Jean Léger, onde aparecem soldados católicos executando duas mulheres, que foram presas nuas com amarras a uma lança e queimadas em "um espeto" (fig. 8).

O gravurista chama a atenção para a barbárie e os atos atrozes dos católicos franceses contra os fiéis da Reforma na França, que são apresentados como mártires. Os católicos que promovem as torturas e execuções, ao queimarem

singularidades da França Antártica, Belo Horizonte, Editora da Universidade de São Paulo/ Editora Itatiaia, 1978, cap. XL, p. 132.

${ }^{37}$ Jean de Léry, op. cit., cap. XV, p. 199. 
as mulheres na fogueira, são colocados aqui na gravura ao nível dos selvagens canibais; os europeus católicos são denunciados e questionados. ${ }^{38}$

Entre finais do século XVI e o decorrer do século XVII, são comuns as imagens feitas por protestantes que mostram os horrores causados pelos espanhóis católicos e a inquisição nos Países Baixos. Todas essas imagens tinham a função de "propaganda", e o gravurista da Histoire Générale des Églises Evangéliques é consciente ao reforçar o terror da cena.

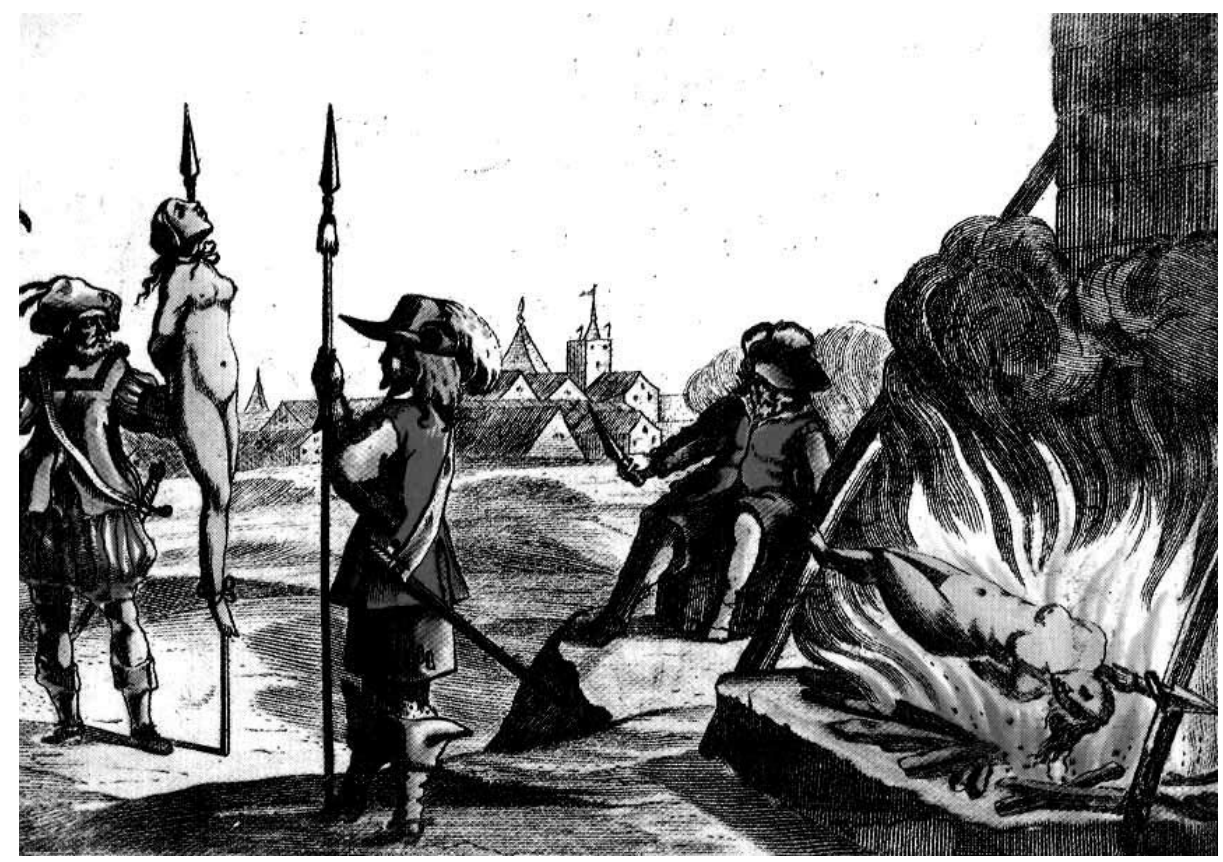

Figura 8 - Gravura Anônima em Histoire Générale des Églises Evangéliques du Piémont ou Vaudoises de Jean Léger. Biblioteca Nacional de Paris. 1669.

Mas não se respondeu à questão satisfatoriamente porque estes exemplos são contemporâneos às imagens da antropofagia americana. A gravura de Holbein levanta dúvidas sobre a origem iconográfica dos espetos e a presença do cavalo entre os ameríndios. Quais são as referências para estas citações? $\mathrm{Na}$ estampa dos cinocéfalos de Fries, de 1525-1527, também aparece uma estra-

\footnotetext{
${ }^{38}$ A associação entre bruxaria e canibalismo é estudada pelo professor Charles Zika, "Body Parts, Saturn and Cannibalism: Visual Representations of witches. Assemblies in the Sixteenth Century", Le Sabbat des Sorciers em Europe (XVe-XVIIIe Siecles), Fontenay-ST. Cloud, École Normale Superieure, 4-7 November, 1992. Exemplar mimeografado, p.16.
} 
nha figura quadrúpede, como nos mapas da cosmografia de Waldseemüller, de 1516, e do próprio Fries, de 1525, nos quais já se tinha levantado algumas questões. Também foi afirmado que na iconografia anterior das cartas ilustradas de Vespúcio não aparecem indicações de espetos. Poderia então se rastear este tipo de representação? Quais seriam os caminhos a trilhar?

Os indícios para rastrear o caminho da pesquisa iconográfica sobre a antropofagia, anterior ao século XV, estão indicados indiretamente por uma citação de Jacques Le Goff sobre a fonte do maravilhoso medieval:

(...) O oceano Índico é um horizonte mental, o exotismo do Ocidente medieval, o lugar dos seus sonhos e dos seus recalcamentos. Explorá-lo é reconhecer uma dimensão essencial da sua mentalidade e da sua sensibilidade, visível em tantos aspectos da arte, um dos principais arsenais da sua imaginação (...). ${ }^{39}$

A resposta é "Oriente", logicamente. Na escrita dos relatos de viagem de finais do século XV e princípios do XVI sobre o Novo Mundo existem similitudes, no estilo entre as descrições do Oriente fantástico e os textos clássicos greco-latinos (Ctesias, Heródoto, Plínio, Solino), e principalmente com os das narrativas de viagens dos séculos XIII-XIV (Plan Carpin, Rubruck, Marco Polo). Com a tradição iconográfica sobre o Oriente aconteceria igual e poderia permitir conexões com as representações do Novo Mundo.

\section{De Gog e Magog ao Índio Canibal}

Algumas das respostas às questões levantadas encontram-se em uma iluminura da Chronica Majora, século XIII, de autoria do inglês Matthew Paris, na qual três mongóis devoram suas vítimas. O mongol da esquerda decepa com um machado uma vítima nua, enquanto seu colega, sentado no corpo do recém-decapitado, devora avidamente duas pernas de outra vítima. O terceiro dos mongóis está sentado entre membros retalhados, duas cabeças e dois braços, enquanto cozinha um corpo humano no espeto. À direita da iluminura aparece um homem nu amarrado a uma árvore pelos braços e cabelos, enquanto ao seu lado um cavalo sobre as duas patas come um ramo da dita árvore (fig. 9).

Matthew Paris cita na Chronica Majora a carta de Henry de Turingia, que descreve a bestialidade dos mongóis

${ }^{39}$ Jacques Le Goff, Para um Novo Conceito de Idade Média. Tempo, trabalho e cultura no Ocidente, Lisboa, Editorial Estampa, 1980, p. 273. 
(...) sunt enim corpore terribiles, vultu furiosi, oculis iracundi, manibus rapaces, dentibus sanguinolenti, et eorum fauces ad carnem hominum comedendam et humanum sanguinem adsorbendum omni tempore sunt paratae (...... ${ }^{40}$

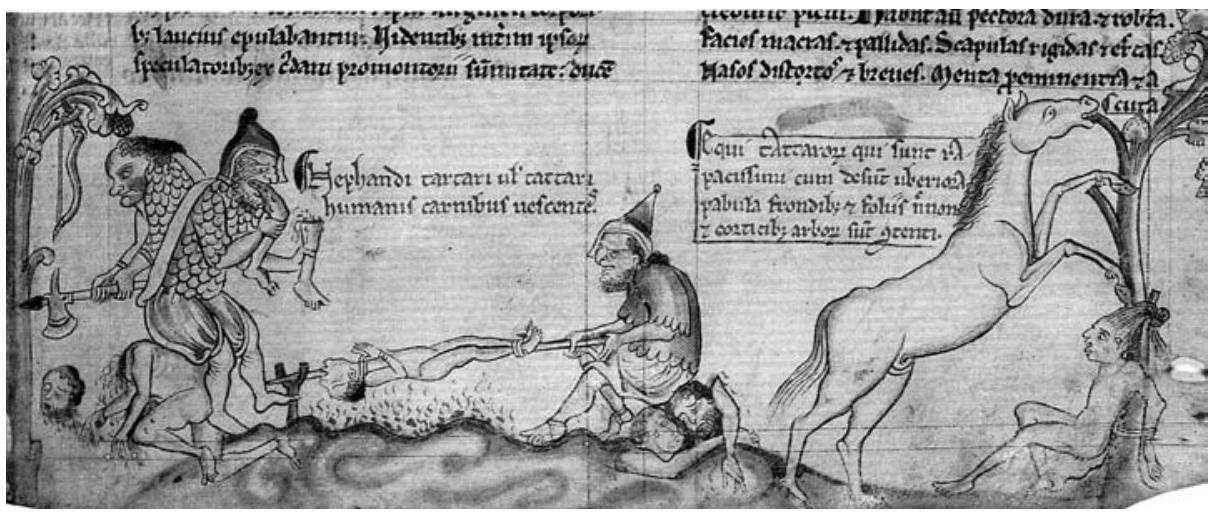

Figura 9-Chronica Majora. Iluminura. Master and Fellows of Corpus Christi College, Cambridge. Século XIII.

Capturar os inimigos, comer sua carne e sorver seu sangue eram características dos anthropophagos desde a tradição clássica, constantemente citadas nas descrições. Plínio comenta na sua História Natural: "IV. Priores Anthropophagos, quos ad septemtrionem esse diximus decem dierum itinere supra Borysthenem amnem, ossibus humanorum capitum bibere, cutibusque cum capillo pro mantelibus ante pectora uti, Isigonus Nicaensis (...)". ${ }^{41}$

Desde a Antiguidade a antropofagia era vista como um vício monstruo$\mathrm{so}^{42}$ e seu caráter destrutivo já está presente na iconografia medieval. Caberia perguntar agora por que essa imagem monstruosa e demonizada dos mongóis. Desde a guerra contra o Império Khwarizm, em 1218, os mongóis ganharam fama de selvageria infinita. Era comum que as cidades que resistiam valente-

40 “(...) Na verdade, há seres de corpos terríveis de expressões furiosas, olhos enraivecidos, mãos rapazes, dentes sanguinolentos e suas goelas foram preparadas para comer a carne dos homens, e sorver o sangue humano em qualquer tempo (...)”. Chronica Majora, VI, 77. Apud W. R. Jones, "The Image of the Barbariam in Medieval Europe", Comparative Studies in Society and history 13, 1971, p. 399.

41 “(...) Segundo Isogne de Niceia, os antopófagos que havíamos nos referido antes, estão a dez dias de caminhada para o norte para lá de Borysthèno, bebem em crânios humanos, que carregam diante de seu peito, como um guardanapo, o couro cabeludo enfeitado (...)". Pline, Naturalis Historia, Liber VII Continetur hominum generatio et institutio, atque inventio artium; II. Gentium mirabiles figura, IV.

${ }^{42}$ Claude Kappler, op. cit. , p. 231. 
mente fossem as mais castigadas e, uma vez tomadas, os mongóis massacravam seus habitantes e as devastavam.

A "matança calculada" era usada como meio para desmoralizar os oponentes. Depois da tomada de Nichapur, todos os sobreviventes homens, mulheres e crianças foram decapitados e seus crânios empilhados em três montes diferentes.

Esta "fama" estava justificada na violenta invasão que assolou reinos e impérios desde a China até a Hungria, destruindo fabulosas capitais como Kiev e Zhongdu, Bagdá e Samarcanda. ${ }^{43}$

Essa imagem aterradora dos mongóis está presente na iluminura corresponde à época das invasões à Europa Oriental (Polônia e Hungria). As histórias sobre as atrocidades dos povos das estepes se espalharam por todo o mundo cristão e islâmico, onde se acreditava que estes povos tinham sido enviados por Deus para punir os pecados da humanidade. A tradição islâmica conta que, em Bucara, Gengis Khan teria dito: "Eu sou o flagelo de Deus. ${ }^{44} \mathrm{Se}$ vocês não tivessem cometido grandes pecados, Deus não lhes teria mandado uma punição como eu". ${ }^{45}$

Era tanto o pavor e medo que os mongóis causaram aos muçulmanos que estes os chamavam de "amaldiçoados de Deus". Este terror também fora compartilhado pelos cristãos. Ivo de Narbonne cita algumas das atrocidades cometidas pelos mongóis: “(...) Virgens foram estupradas atémorrerem de exaustão; então seus seios foram cortados para servirem de acepipes aos chefes deles (...)". ${ }^{46}$

Os mongóis, na primeira metade do século XIII, seriam associados aos inclusi ${ }^{47}$ ou seja, os povos lendários de Gog e Magog, habitantes da Ásia ferozes e aterradores das regiões situadas além do Cáucaso e das montanhas Cáspias, "comedores de carne humana". A Chronica Majora os descrevia da seguinte maneira:

\footnotetext{
${ }^{43}$ Verbete Gêngis Khan. Henry R. Loyn (Org.), Dicionário da Idade Média, Rio de Janeiro, Jorge Zahar Editor, 1992, p. 164.

${ }^{44}$ O epíteto de "flagelo de Deus" já tinha sido usado por Átila o Cã dos Hunos na invasão do Império Romano de Ocidente no século V. Para aprofundar no assunto ver Lucien Musset, Las oleadas germânicas, Barcelona, Editorial Labor, 1977 e L. Hambis, Attila et les Huns, Paris, PUF, 1972.

${ }^{45}$ Gêngis Khan, no ano de 1219, dirigia-se desta forma aos refugiados numa mesquita em Bucara, na Ásia Central. Apud Fergus Fleming (Ed.), Conquistas Mongólicas 1200-1300, Rio de Janeiro, Editores de Time-Life Livros e Editora Cidade Cultural, 1991, p. 9.

${ }^{46}$ Ivo de Narbonne, Apud Fergus Fleming, op. cit., p. 25.

${ }^{47}$ Termo utilizado para se referir ao isolamento no qual estariam estes povos lendários, situação característica dos monstros e das maravilhas. Kappler, op. cit., p. 238.
} 
(...) Perfurando as sólidas rochas do Cáucaso, eles se espalharam como demônios do inferno de Tártaro. Assolaram a face da terra como uma praga de gafanhotos e causaram uma devastação terrível na parte oriental da Europa, flagelando-a com fogo e carnificina (....). ${ }^{48}$

A primeira citação de Gog e Magog encontra-se na Bíblia, em Ezequiel, ${ }^{49}$ que identifica essas tribos com os Cimérios. Já no livro do Apocalipse,,$^{50} \mathrm{a}$ identificação é feita com os Citas.

A lenda de Gog e Magog presente na mitologia judia, cristã e muçulmana mistura duas tradições, uma bíblica e outra helenística. Segundo a lenda, estes povos foram presos nas terras setentrionais por Deus a pedido de Alexandre, que os tinha derrotado, para que não se dispersassem pelo mundo. A escatologia cristã medieval indicava que quando retornasse o Anticristo, as tribos de Gog e Magog seriam liberadas e destruiriam a cristandade.

As constantes invasões mantinham viva a lenda e autores antigos e medievais como Comodiano, Ambrósio, Orósio e Isidoro, entre outros, que associariam Gog e Magog com os nômades das estepes; Citas, Hunos, Alanos, Avaros e Tártaros. ${ }^{51}$

(...) the legend of Alexander and the inclosed nations served not only to identify the various historical challengers of civilization but also gave hope for the eventual triumph of Christian civilization over the forces of Antichrist. The eschatological content of the story of God and Magog both satisfied European curiosity about an astonishing and frightening people, the Tartars, and reassured medieval man that they occupied a place in the Christian plan of salvation (.....52

As imagens dos mongóis vão mudar ao longo do século XIII; de terríveis inimigos, povos de Gog e Magog, passam a potenciais aliados contra o Islam. A prova dessa mudança está nas missões enviadas posteriormente pelo papa Inocêncio IV à China e no "tom" dos relatos e descrições de Plano Carpini,

${ }^{48}$ Matthew Paris, Chronica Majora, Apud Fergus Fleming, op. cit., p. 9.

49 “(...) Gomer com todas as suas tropas, Bet-Togorma, situada no extremo norte, com todas as suas tropas, povos numerosos contigo (...)”. Ezequiel 38, 6. Sobre Gog e Magog, ver Ezequiel, 38-39.

50 “(...) Quando se completarem os mil anos, Satanás será solto de sua prisão e sairá para seduzir as nações dos quatro cantos da terra, Gog e Magog, reunindo-os para o combate; seu número é como a areia do mar... Subiram sobre a superfície da terra e cercaram o acampamento dos santos e a Cidade amada, mas um fogo desceu do céu e os devorou (...)". Apocalipse 20, 7-10.

${ }^{51}$ W. R. Jones, "The Image of the Barbariam in Medieval Europe", Comparative Studies in Society and history 13, 1971, p. 399.

${ }^{52}$ Jones, op. cit., p. 400. 
Rubruck e Marco Polo, mas que ainda sobreviveram alguns vestígios da antropofagia entre os mongóis, justificada por condições extremas, ou que em outros casos acabaram transferidas a outros povos.

Das tribos de Gog e Magog chegam representações imagéticas mais fortes e detalhadas da antropofagia medieval e na medida em que estas tribos sejam identificadas com determinados povos "reais", estes últimos ganharão características monstruosas.

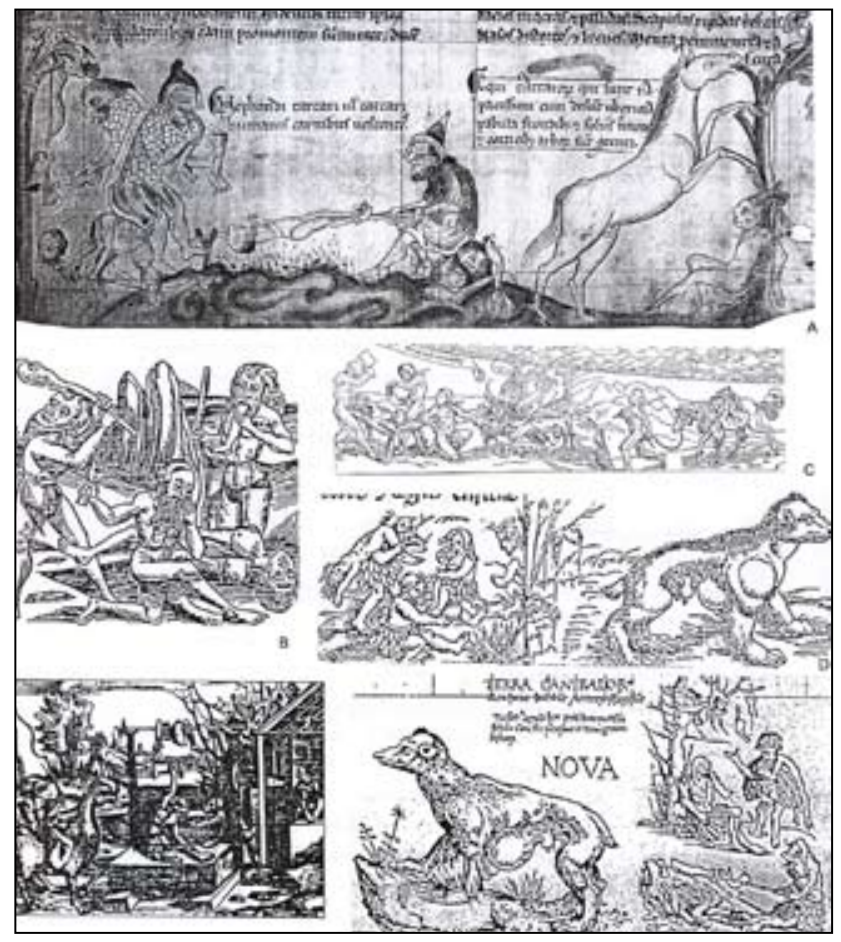

Figura 10 - Detalhes de cenas de antropofagia: A) Chronica Majora. Iluminura. Cambridge. Século XIII; B) Sebastião Brant. Fábulas de Esopo. Xilogravura. 1501; C). Hans Holbein. Novus Orbis Regionum, 1532; D) Lorenz Fries/Martin Waldseemüller. Terra Nova. 1541; E) Lorenz Fries, Canibais com cabeça de cachorro. 1525-1527; F) Martin Waldseemüller. Terra Canibalorum. 1516.

(...) o canibalismo é um vício monstruoso e o maior fundamento para essa opinião é que os antropófagos figuram no rol dos monstros desde a Antiguidade. É esse caráter aprioristicamente monstruoso da antropofagia que leva os 
viajantes a fabularem e a dotarem os antropófagos com atributos efetivamente monstruosos: cabeça de cão ou olho único (......$^{53}$

A iluminura da Chronica Majora apresenta os quatro momentos da prática antropofágica: 1. a vítima acorrentada esperando pelo seu terrível destino (à direita, ao lado da árvore e do cavalo); 2. um guerreiro executa, decapitando com uma machadinha, uma das vítimas, que também serve de banco para outro mongol (à esquerda); 3. a carne humana é preparada no espeto pelo guerreiro que está sentado sobre cabeças e braços decepados (ao centro) e 4. finalmente, a vítima é devorada pelo mongol que está sentado sobre uma vítima recentemente decapitada (à esquerda) (fig.10).

A presença do cavalo ao lado da vítima teria sentido porque os mongóis eram nômades e exímios ginetes das estepes. Este tipo de imagem encontra conexões com as xilogravuras do século XVI, especialmente com a vinheta do mapa de Hans Holbein e a estampa dos cinocéfalos de Lorenz Fries porque nestas duas imagens os canibais trazem na sua montaria uma vítima presa. Em Holbein, a montaria é claramente um cavalo; em Fries, é um monstro híbrido que desempenha a mesma função do cavalo. Nos mapas de 1516 e 1522, de Waldseemüller e de Fries, também aparecem as vítimas, já não acorrentadas às montarias, mas levadas nas costas (de cabeça para baixo) pelos próprios canibais de barbas e saias de penas. Nestes dois mapas não aparecem cavalos, mas dois monstros gigantescos ao lado dos canibais; o esquema é o mesmo.

Tanto na iluminura do século XIII como nos mapas de Waldseemülher e Fries, os elementos em cena são idênticos: três canibais, uma vítima ainda viva e um ser quadrúpede, seja cavalo ou monstro. Na xilogravura da Esopi Fabularum, de 1501, autoria de Sebastião Brant, também são três selvagens que participam do episódio atacando e devorando a vítima. Note-se que o selvagem que devora uma perna, à direita da estampa, é similar ao mongol da iluminura da chronica, que devora duas pernas. A posição dos braços do guerreiro mongol e do selvagem das florestas é parecida; o braço que empunha a perna que está sendo devorada nas duas imagens está flexionado. Enquanto o outro braço aparece estendido, o selvagem da xilogravura de Brant empunha um pau e o guerreiro mongol empunha outra perna humana, que está prestes a devorar.

O feroz antropófago barbado da iluminura da Chronica Majora está sentado sobre duas cabeças e dois braços, com uma perna flexionada e outra

${ }^{53}$ Kappler, op. cit., p. 231. 
esticada, assando sua vítima num espeto que segura com as duas mãos. Ela está empalada porque o pau do espeto lhe atravessa o corpo saindo pela boca.

Quando se compara o mongol que segura o espeto da iluminura com os índios canibais das cosmografias de Lorenz Fries e Martin Waldseemüller, é surpreendente a similitude das posturas dos canibais do Novo Mundo, que também aparecem sustentando o espeto com as duas mãos. Na xilogravura do mapa de 1522 coincidem as posições das pernas (uma dobrada e outra esticada). Diferentemente da iluminura do século XIII, os espetos dos mapas são partes decepadas e não o corpo completo da vítima.

As imagens dos espetos giratórios encontram também seu referente na tradição medieval. No século XII, a força propulsora do combate às heresias gerou uma escatologia em favor da máquina judicial. ${ }^{54}$ Assim, as penas da justiça secular são integradas como tormentos aos pecadores nas representações pictóricas do inferno, onde cada alma seria julgada de acordo com o balanço das próprias ações. ${ }^{55}$ Lewis Hanke oportunamente comenta:

(...) tenderam a olhar o Novo Mundo através de óculos medievais. A riqueza de ideias e lendas desenvolvidas tão luxuriosamente na Idade Média transferiuse imediatamente para América; e esta influência medieval ficou marcada principalmente nos primeiros anos da descoberta e da conquista (...). ${ }^{56}$

As imagens alemãs sobre o canibalismo feitas na primeira metade do século XVI associaram o consumo da carne humana a banquetes e festins, como atitudes quotidianas dos ameríndios.

\section{Considerações Finais}

Os artistas criadores da iconografia do índio do Brasil são também impressores, editores, livreiros e comerciantes, e principalmente colecionadores de estampas, de gravuras em madeira e metal, além de testemunhas atentas das novas obras ilustradas que saem ao mercado. Esses artesãos não só colecionam, mas também aproveitam, reciclam, selecionam e adaptam imagens que durante séculos continuaram circulando, perdendo seus referentes e fins originais. Na realidade, tais imagens foram ganhando novos referentes e significados, que por sua vez ganham novos re-significados ao entrar em contato

${ }^{54}$ Luther Link, O Diabo. A máscara sem rosto, São Paulo, Companhia das Letras, 1998, p. 129.

${ }^{55}$ Georges Minois, História dos Infernos, Lisboa, Editorial Teorema, 1997, p. 206.

${ }^{56}$ Lewis Hanke, Aristóteles e os Índios americanos, São Paulo, Livraria Martins, s/d, p. 19-20. 
com diferentes grupos sociais. Esta situação será cada vez mais comum durante o século XVI, com o desenvolvimento da imprensa e com as técnicas cada vez mais sofisticadas das gravuras.

No presente artigo, foi abordado o estudo da genealogia da imagem como um recurso para rastrear diálogos entre as diferentes fontes e tradições textuais e visuais, que foram as coordenadas familiares, os pontos de partida e as fontes das gravuras do século XVI. São considerados como fontes: a Bíblia, a Idade Dourada de Ovídio, os textos apócrifos, a Lenda Áurea, os relatos de viagem ao Ocidente, como os de São Brandão e ao Oriente como os relatados por Polo, Séverac ou Mandeville, a teratologia clássica e medieval com seus selvagens dos bosques, os cinocéfalos e seus aterradores inclusi presentes nos escritos dos santos cristãos, na hagiografia e nos sermões, as Lendas como a de Alexandre, os tratados, as crônicas como a Chronica Majora, as obras clássicas como a História Natural de Plínio, a Geografia de Ptolomeu, a Cartografia medieval e renascentista, as imagens judiciais, os manuscritos iluminados, os saltérios, os poemas e as fabulas ilustradas como, as de Sebastião Brant. Essas fontes conhecidas pelos artistas são os pontos de partida para gerar novas imagens, novos temas, novos relatos, novas apropriações e re-significações sobre o Novo Mundo e seus habitantes.

O próprio E. H. Gombrich enfatiza que uma imagem nunca parte do nada e sempre se faz necessário um referencial em que se apoiar. Ele afirma que:

(...) O gênio original que pinta "o que vê" e cria formas novas a partir do nada é um mito romântico. Mesmo o maior artista precisa de um idioma com que trabalhar. Somente a tradição, tal como ele a encontra, pode propiciar-lhe a matéria-prima da imaginária de que ele precisa para representar um evento ou um "fragmento da natureza". Ele pode remodelar essa imaginária, adaptá-la à sua tarefa, assimilá-la às suas necessidades e mudá-la de tal forma que não seja mais reconhecida, mas não pode representar o que está diante de seus olhos sem um acervo preexistente de imagens adquiridas, do mesmo modo que não pode pintá-la sem o conjunto preexistente de cores que precisa ter em sua paleta (...). ${ }^{57}$

Os sentidos que possuíam as imagens não são perenes, constantes nem universais, pois estas são construídas interpretadas, re-significadas, mantidas alteradas no tempo e em cada uso social. Seu significado também é

${ }^{57}$ E. H. Gombrich, Meditações sobre um cavalinho de pau e outros ensaios sobre a teoria da arte, São Paulo: EDUSP, 1999, p. 126. 
transformado pela apropriação dos indivíduos ou grupos. Assim, tanto para o produtor da imagem como para o mecenas que a encomenda, o sentido pode ser um. Contudo, quando a imagem circula entre diferentes grupos sociais, sua natureza polissêmica permite que ganhe novos significados, significantes, interpretações e usos. É desse modo que devem ser pensadas as gravuras sobre os habitantes do Novo Mundo, feitas por artistas como Holbein ou Münster, que acompanhavam a cartografia e os relatos de viagem impressos na primeira metade do século XVI e consumidos pelas elites cultas nas cidades italianas, francesas e do Sacro Império, como também por grupos mais amplos da sociedade, por intermédio da circulação de estampas e folhas soltas. 